\title{
DYNAMICS OF LEAF FALL FROM RIPARIAN VEGETATION AND THE ACCUMULATION IN BENTHIC STOCK IN NEOTROPICAL STREAMS ${ }^{1}$
}

Leandro Fabrício Fiori² ${ }^{*}$, Vivian de Mello Cionek ${ }^{2}$, Patricia Almeida Sacramento ${ }^{2}$ e Evanilde Benedito ${ }^{3}$

\footnotetext{
${ }^{1}$ Recebido em 25.06.2014 aceito para publicação em 30.11.2015.

${ }^{2}$ Universidade Estadual de Maringá, Programa de Pós-Graduação em Ecologia de Ambientes Aquáticos Continentais, Maringá, Paraná - Brasil. E-mail: <leandrofiori_8@hotmail.com>, <viviancionek@gmail.com>e < pasacramento@yahoo.com.br>.

${ }^{3}$ Universidade Estadual de Maringá, Departamento de Biologia, Programa de Pós-Graduação em Ecologia de Ambientes Aquáticos Continentais, Maringá, Paraná - Brasil. E-mail: <eva@nupelia.uem.br>.

*Autor para correspondência.
}

\begin{abstract}
Considering the importance of the riparian vegetation leaves as an energetic source to first order streams, the aim of the present study was to evaluate the leaf biomass contribution to the system and its temporal dynamics. With this purpose, monthly samples from July 2008 to June 2009 were collected using four sampling devices installed in three streams, in order to collect the vertical, lateral and terrestrial loads, and the benthic stock. We tested the following hypothesis: (1) leaf biomass input is higher after hydric stress periods; and (2) benthic stock biomass increase with higher loads from vertical and lateral entrances. Leaves represented $71.9 \%$ (on average) of all sampled allochthonous matter, with seasonal significant variation along the studied year. Peaks of leaf input were registered in September-October, after an increase in rainfall, and also in January, after a decrease in rainfall. Leaf input was higher in the lateral load.
\end{abstract}

Keywords: Energy transfer; First order streams; Allochthonous organic matter.

\section{DINÂMICA DA QUEDA FOLIAR DA VEGETAÇÃO RIPÁRIA E ACÚMULO NO ESTOQUE BENTÔNICO EM RIACHOS NEOTROPICAIS}

\begin{abstract}
RESUMO-Considerando a importância de folhas da vegetação ripária como fonte energética para riachos de pequeno porte, este estudo teve por objetivo avaliar a contribuição de biomassa de folhas para o sistema e a dinâmica de aporte temporal. Para tanto, amostras mensais de julho de 2008 a junho de 2009 foram coletadas utilizando quatro amostradores instalados em três riachos, a fim de coletar os aportes vertical, lateral e terrestre e o estoque bentônico. Foram testadas as hipóteses de que: (1) o aporte de biomassa de folhas é maior após periodos de estresse hídrico; e (2) a biomassa do estoque bentônico aumenta com o incremento dos aportes lateral e vertical. As folhas representaram, em média, 71,9\% de todo o material alóctone amostrado, com variação sazonal significativa ao longo do ano. Os picos de entrada de folhas foram registrados em setembro-outubro, após um período de aumento na pluviosidade, e também em janeiro, após decréscimo na pluviosidade. A maior entrada de folhas se deu pelo aporte lateral.
\end{abstract}

Palavras-chave: Transferência de energia; Riachos de primeira ordem; Matéria orgânica alóctone. 


\section{INTRODUCTION}

Allochthonous organic matter (AOM) is the main source of carbon to aquatic communities from first order streams (TREVISAN; HEPP, 2007), since shading produced by tree canopy reduces light penetration and consequently influence the autochtonous production (VANNOTE et al., 1980; ABELHO, 2001; HAUER; HILL, 2006). Streams that drains through preserved forested areas receive allochthonous organic matter inputs all year long. The amount and type of AOM input is influenced by the different reproductive periods of each species; by the frequency and magnitude of rainfall and drought; and the steepness of the stream banks (MAGANA, 2001; GONÇALVES; CALLISTO, 2013). Secondary production in streams is highly dependent on AOM input, represented by leaves, branches, fruits, invertebrates and nutrients from the watershed, with special regard to leaves, that can represent up to $74 \%$ of all vegetal organic matter that entry stream channels (GONÇALVES; CALLISTO, 2013).

Leaves can increase habitat diversity, providing shelter for small fish and invertebrates, and it can be used as substrate for microorganisms and food source to some organisms (SANPERA-CALBET et al., 2009) and provide energy source for the entire system, both in coarse or particulate organic matter forms. According to Vannote et al. (1980), the organic matter that enters the streams are accumulated, processed and transported through the river continuum, and the labile compounds are rapidly consumed by aquatic organisms, while the refractory ones can be exported downstream and latter accumulated on the river bed.

Because leaves are such an important energetic component to first order streams, the aim of the present study was to evaluate its temporal dynamics and biomass contribution to the system in a Semi-Decidual Forest. We tested the following hypothesis: (1) leaf biomass input is higher after hydric stress periods; and (2) benthic stock biomass increase with higher loads from vertical and lateral entrances.

\section{MATERIALAND METHODS}

\subsection{Study area}

The studied streams are located in Northwest of Paraná State (Figure 1), under the domains of the SemiDeciduous Forest. Two of these streams drain inside

Revista Árvore, Viçosa-MG, v.40, n.1, p.89-96, 2016
Caiuá Ecological Station (CES) and one inside State Park of Amaporã (SPA), protected forest fragments of the region. In CES, especially in the riparian vegetation, there is a high variety of native species, along with rare and endangered species. Families with higher richness are Leguminosae, Myrtaceae e Lauraceae (PEREIRA, 2012). Conceição Stream (22³5'15.0"S $\left.52^{\circ} 53^{\prime} 29.0^{\prime \prime} \mathrm{W}\right)$ starts flowing inside CES, has $450 \mathrm{~m}$ in length, of which the final $100 \mathrm{~m}$ forms a swamp before it discharge into Paranapanema river. It has about 1 $\mathrm{m}$ width and $10 \mathrm{~cm}$ depth, with an average water velocity of $0.126 \mathrm{~m} / \mathrm{s}$. Its banks present little steepness, are well protected by a dense riparian cover, with a diversity of vegetation layers such as herbaceous, shrubs and trees with different heights and thickness. Litter leaf accumulates on the banks and margins, protecting the soil and are promptly available to reach the stream channel. At the same location flows Scherer Stream (22 36'6.7"S 52 $\left.53^{\circ} 2.0^{\prime \prime} \mathrm{W}\right)$ with $1600 \mathrm{~m}$ in length and discharges into Paranapanema river. It has an average $1.12 \mathrm{~m}$ width and $13 \mathrm{~cm}$ depth, with an average water velocity of $0.204 \mathrm{~m} / \mathrm{s}$. Its banks are very steep, with erosion signs along the entire stream, and frequently, large trees fall into the stream due to the erosion process. There are high leaf litter accumulation over the banks and immediate margins, some can readily reach stream' channel, while other are frequently buried by bank displacement due to erosion.

Amaporã State Park represents a pristine forest fragment with species such as ipês (Tabebuia heptaphylla), Perobas (Aspidosperma polyneuron) and Cedros (Cedrela fissilis) (IAP, 1996). This fragment presents signs of dominance of secondary forest species along its boarders due to negative impacts inflicted to the fragments before the establishment of protected areas by law (PEREIRA, 2012; IAP 1996). Jurema Stream

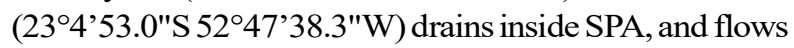
for approximately $1 \mathrm{~km}$ before discharge into an artificial lake used for recreation in the Park. It has an average $2.8 \mathrm{~m}$ width and $18.5 \mathrm{~cm}$ depth, with an average water velocity of $0.233 \mathrm{~m} / \mathrm{s}$. There are reaches with high and low steepness, well protected by the riparian cover, and so, with little erosion signs. There are diverse vegetation layers, comprised of herbaceous, shrubs and different trees with a variety of heights and thickness. There are high litter accumulation on the banks and margins, protecting the soil and promptly available to entry the stream' channel. 


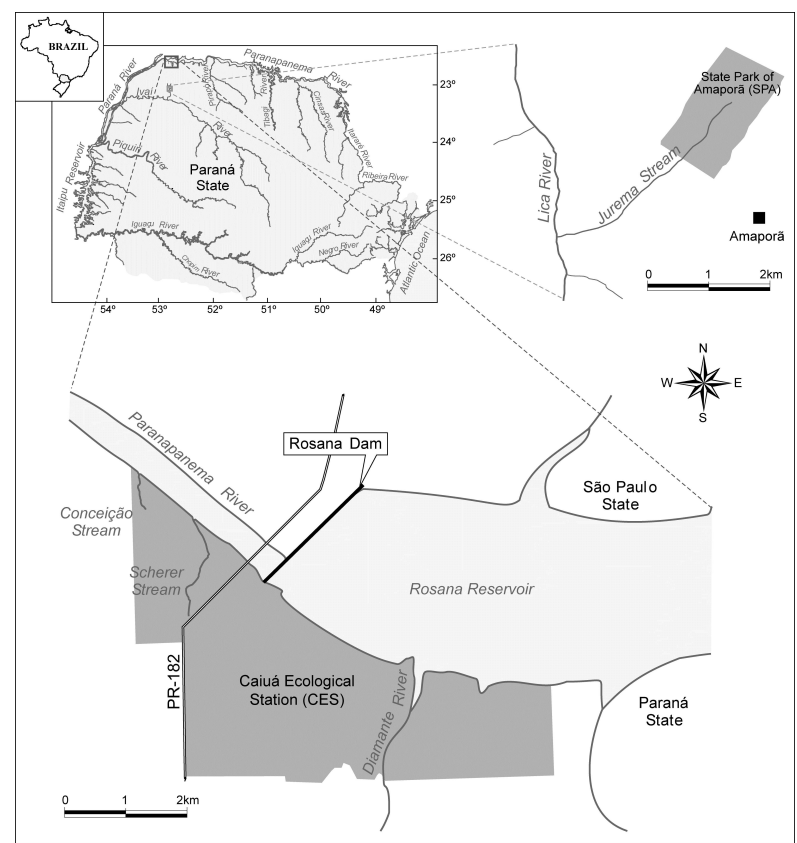

Figure 1 - Sampled streams: Conceição and Scherer in Caiuá Ecological Station and Jurema in State Park of Amaporã.

Figura 1 - Córregos amostrados: Conceição e Scherer na Estação Ecológica do Caiuá e Jurema no Parque Estadual de Amaporã.

\subsection{Sampling}

Sampling of allochthonous organic matter was taken monthly, between July 2008 and July 2009. Sampling methods were based on those proposed by Gonçalves et al. (2006). In order to measure the biomass input of leaves into the streams, and considering the streams' small extent, all samplers were exposed throughout the longitudinal gradient of the streams, in three equally distant stretches in both banks, with a maximum extent of $450 \mathrm{~m}$ between the first and last sampler, as follows:

1. The input of coarse particulate organic matter (CPOM) to the forest floor was quantified using twelve nets $\left(1 \mathrm{~m}^{2}, 5 \mathrm{~mm}\right.$ mesh size) displayed randomly, six at each margin, called terrestrial load (Figure 2), which represents the potential stock that can be transported into the stream.

2. Vertical load of AOM was measured through the suspension of twenty-four plastic buckets $(12 \mathrm{~cm}$ in diameter) above and across the stream channel, in six equally distant lines with four buckets, called vertical load (Figure 2), that represents the direct input to the streams. The area calculation was performed using the equation:

$$
\mathrm{A}=\pi * \mathrm{R}^{2}
$$

were $\mathrm{A}$ is the circle area; $\pi=3.1416 ; \mathrm{R}=$ radius of the bucket.

3.CPOM that flow from the soil into the stream was sampled using twelve rectangular nets (net opening $=0.20 \times 0.40 \mathrm{~m}=0.08 \mathrm{~m}^{2}$ ) exposed in both banks, six at each bank, called lateral load (Figure 2), which represents indirect or horizontal load.

4. CPOM deposited on the streambed was collect using a PVC square of $0.5 \mathrm{~m}^{2}$ (twelve replicates), randomly distributed through the stream, called benthic stock (Figure 2), representing the standing stocks in the channel.

The catch per unit effort (CPUE) was calculated to ensure biomass of different samplers to be comparable, expressed in total dry weight $\left(\mathrm{g} \cdot \mathrm{m}^{-2}\right.$. year-1 $)$ of net. For this calculation, we used the equation: $\mathrm{CPUE}=\left(\mathrm{W}_{\mathrm{t}} / \mathrm{E}\right)$; were, $\mathrm{W}_{\mathrm{t}}=$ total dry weight sampled, $\mathrm{E}=$ effort $\left(\mathrm{m}^{-2}\right.$ of net per 30 days of sampling). Rainfall data for CEE was obtained from Duke Energy in Rosana Dam, and for SPA, from the own Park records.

\subsection{Data analysis}

The Kruskal-Wallis test was applied to biomass data to verify for temporal variation along the sampling months. Analyses were performed with inputs and standing stock separately. Pearson correlation tests were applied between benthic stock and vertical and lateral loads to verify for association of inputs and retention of leaves; and between rainfall and direct leaf fall $(\mathrm{Vi}+\mathrm{Ti})$, to analyze the influence of rainfall over leaf fall.

\section{RESULTS}

In Jurema Stream we recorded 2914.5 g.m. ${ }^{-2}$.year ${ }^{-1}$ (dry weight) of leaf input and $105.3 \mathrm{~g} . \mathrm{m}^{-2}$.year ${ }^{-1}$ for benthic stock, that corresponded to $75.4 \%$ of the sampled material. The sampled material includes leaves, branches, flowers and insects. In Scherer Stream we registered 4289.3 g. $\mathrm{m}^{-2}$.year ${ }^{-1}$ (dry weight) of leaf input and 329.2 g. $\mathrm{m}^{-2}$.year ${ }^{-1}$ for benthic stock, corresponding to $69.9 \%$ of the sampled material. In Conceição Stream we sampled 
3506.0 g. $\mathrm{m}^{-2}$. year ${ }^{-1}$ (dry weight) of leaf input and 430.5 g. $\mathrm{m}^{-2}$.year-1 for benthic stock, that corresponded to $70.5 \%$ of the sampled material.
The leaf biomass of lateral, vertical and terrestrial loads and benthic standing stock varied temporally in all three streams (Table 1).

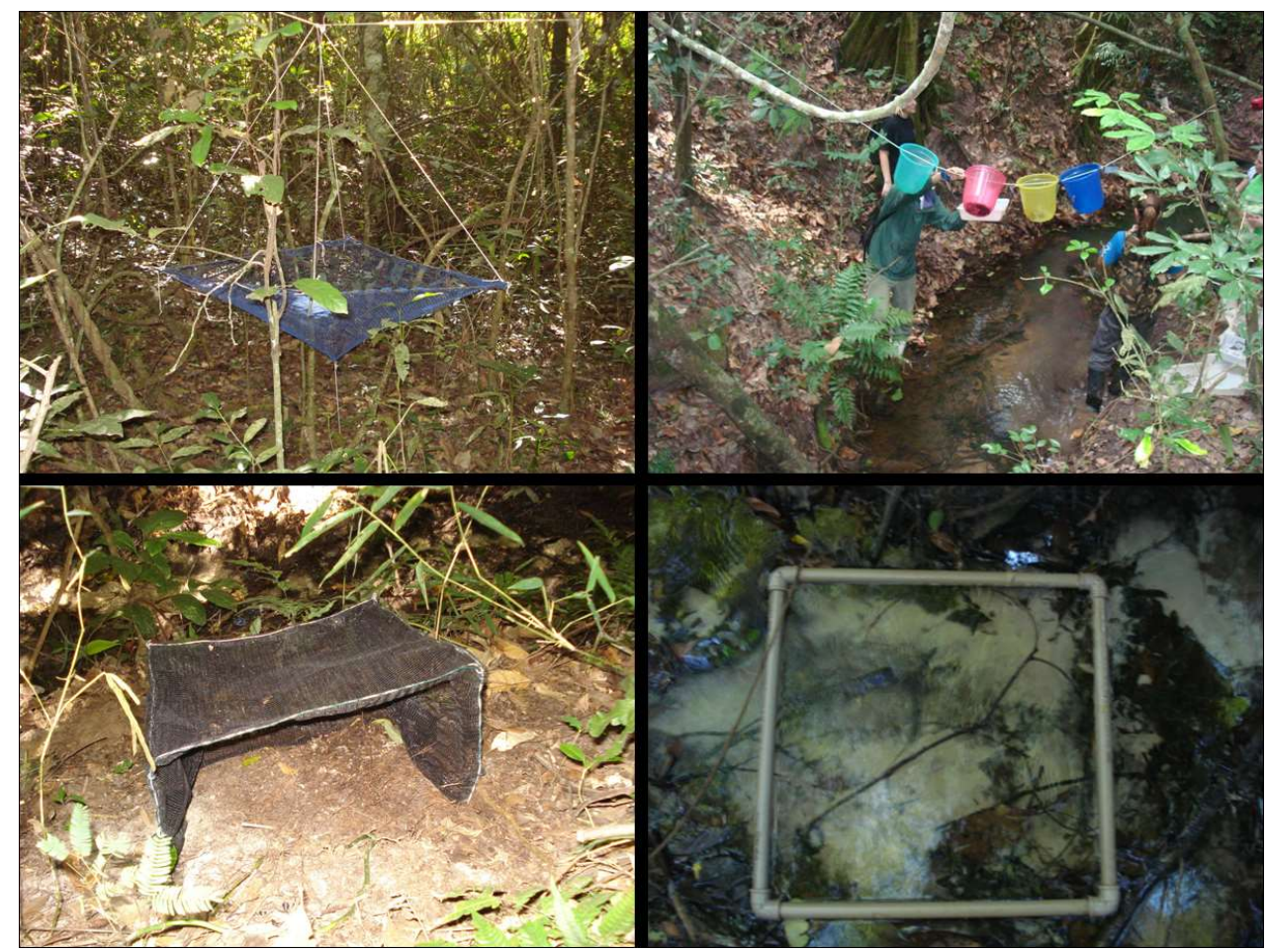

Figure 2 - Sampling devices: Terrestrial load (upper left); Vertical load (upper right); Lateral load (down left); and Benthic stock (Down right).

Figura 2 - Dispositivos de amostragem: Entrada Terrestre (canto superior esquerdo); Entrada vertical (canto superior direito); Entrada lateral (canto inferior à esquerda); e Estoque bentônico (canto inferior à direita).

Table 1 - Kruskal-Wallis test for annual variation of leaf biomass for each of the sampling devices.

Tabela 1 - Teste Kruskal-Wallis para a variação anual de biomassa de folhas de cada um dos dispositivos de amostragem.

\begin{tabular}{|c|c|c|c|c|}
\hline Sampling device & $\mathrm{n}$ & $\mathrm{df}$ & $\mathrm{H}$ & $\mathrm{p}$ \\
\hline \multicolumn{5}{|l|}{ Jurema } \\
\hline Vertical input & 339 & 11 & 83.0 & 0.0001 \\
\hline Lateral input & 115 & 11 & 22.0 & 0.0245 \\
\hline Terretrial input & 118 & 11 & 43.0 & 0.0001 \\
\hline Benthic stock & 115 & 11 & 53.1 & 0.0001 \\
\hline \multicolumn{5}{|l|}{ Scherer } \\
\hline Vertical input & 250 & 11 & 83.3 & 0.0001 \\
\hline Lateral input & 110 & 11 & 45.7 & 0.0001 \\
\hline Terretrial input & 123 & 11 & 38.3 & 0.0001 \\
\hline Benthic stock & 115 & 11 & 28.0 & 0.0032 \\
\hline \multicolumn{5}{|l|}{ Conceição } \\
\hline Vertical input & 210 & 11 & 60.3 & 0.0001 \\
\hline Lateral input & 119 & 11 & 50.6 & 0.0001 \\
\hline Terretrial input & 131 & 11 & 77.3 & 0.0001 \\
\hline Benthic stock & 116 & 11 & 46.4 & 0.0001 \\
\hline
\end{tabular}

Revista Árvore, Viçosa-MG, v.40, n.1, p.89-96, 2016 


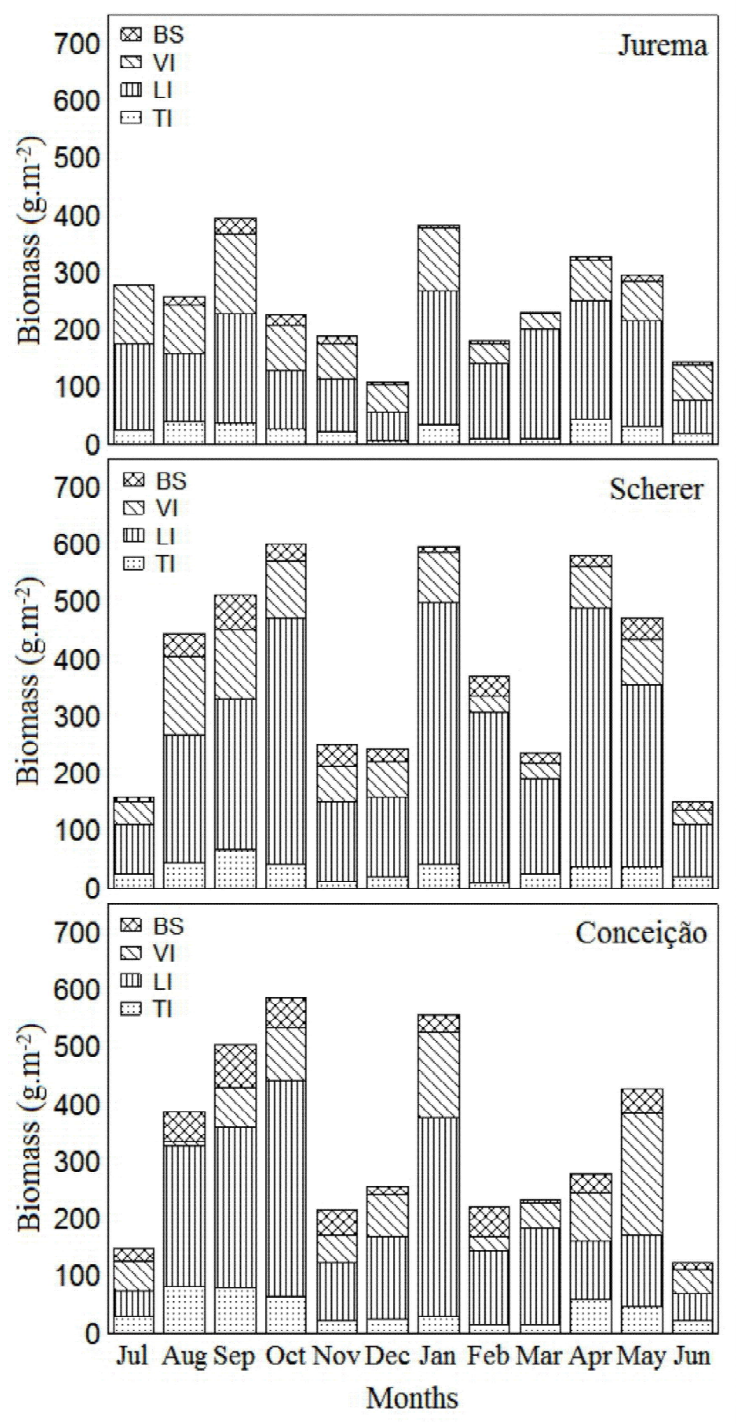

Figure 3 - Biomass $\left(\mathrm{g} \cdot \mathrm{m}^{-2}\right.$ ) of the Benthic Stock (BS), Vertical load (VI), Lateral load (LI), Terrestrial load (TI), in Jurema, Scherer and Conceição Streams, between July 2008 and June 2009.

Figura 3 -Biomassa $\left(\mathrm{g} \cdot \mathrm{m}^{-2}\right)$ do Estoque Bentônico (BS), Entrada Vertical (VI), Entrada Lateral (LI) e Entrada Terrestre (TI), nos Riachos Jurema, Scherer e Conceição, entre julho de 2008 e junho 2009.

The peaks of leaf biomass input, considering all samplers, was registered in September and January for Jurema, in August, September and October for Scherer, while for Conceição in September, October and January. Regarding samplers separately, the lateral load had the highest biomass for the three streams, especially in Scherer (Figure 3). Benthic stock had the highest biomass in Conceição, which presents the slowest water velocity and higher accumulation of organic matter in the channel.

Direct leaf biomass input to the stream and forest soil (VI + TI) had no correlation with rainfall during the studied year for Jurema Stream ( $r$ Pearson $=0.095$; $\mathrm{p}=0.653)$, Scherer Stream $(\mathrm{r}$ Pearson $=0.290 ; \mathrm{p}=0.359)$ and Conceição Stream ( $\mathrm{r}$ Pearson $=0.151 ; \mathrm{p}=0.638$ ) (Figure 4).

The benthic stock was positively correlated with vertical load in Jurema Stream ( $r$ Pearson $=0.595 ; p$ $=0.04)$ and Scherer Stream $(r$ Pearson $=0.611 ; p=0.03)$. In Conceição Stream, benthic stock was not correlated with the lateral or vertical loads.

\section{DISCUSSION}

Leaves were the most abundant component of the allochthonous organic matter input to the streams (average $71.9 \%$ ) and their dominance in the litter composition can be an influence of the evergreen characteristic of the semi-deciduous forest that provides this component throughout the year. The leafs contribute greatly to energy flow in the system (CARVALHO; UIEDA, 2010), since the starting point for energy distribution in aquatic ecosystems occurs in first order streams, where specialized organisms consume and process the organic matter, that, in the end, will be available to the rest of the system (VANNOTE et al., 1980). The higher leaf contribution as allochthonous energy source to streams has been reported by other studies (MINSHALL, 1967; PAGANO; DURINGAN, 2000; GREGÓRIO et al., 2007; NIN et al., 2009; GONÇALVES etal., 2014). It could be related to a favorable combination of solar radiation, high temperature and abundant rain and nutrients in the tropics, which culminates in high production of vascular plants in riparian vegetation (RICKLEFS, 2010).

Leaf biomass input can vary during the year, and in spite the significant variation registered for the studied streams, with distinguishable peaks, it is possible to verify that leaf input and stock occur all year long. Defined peaks tend to occur during autumn in temperate streams (NIN et al., 2009), but can occur in tropical streams as well. Studies of organic matter input to tropical streams flowing inside Semi-Deciduous (VITAL et al., 2004) and Atlantic Rain Forests (FRANÇA et al., 2009),

Revista Árvore, Viçosa-MG, v.40, n.1, p.89-96, 2016 


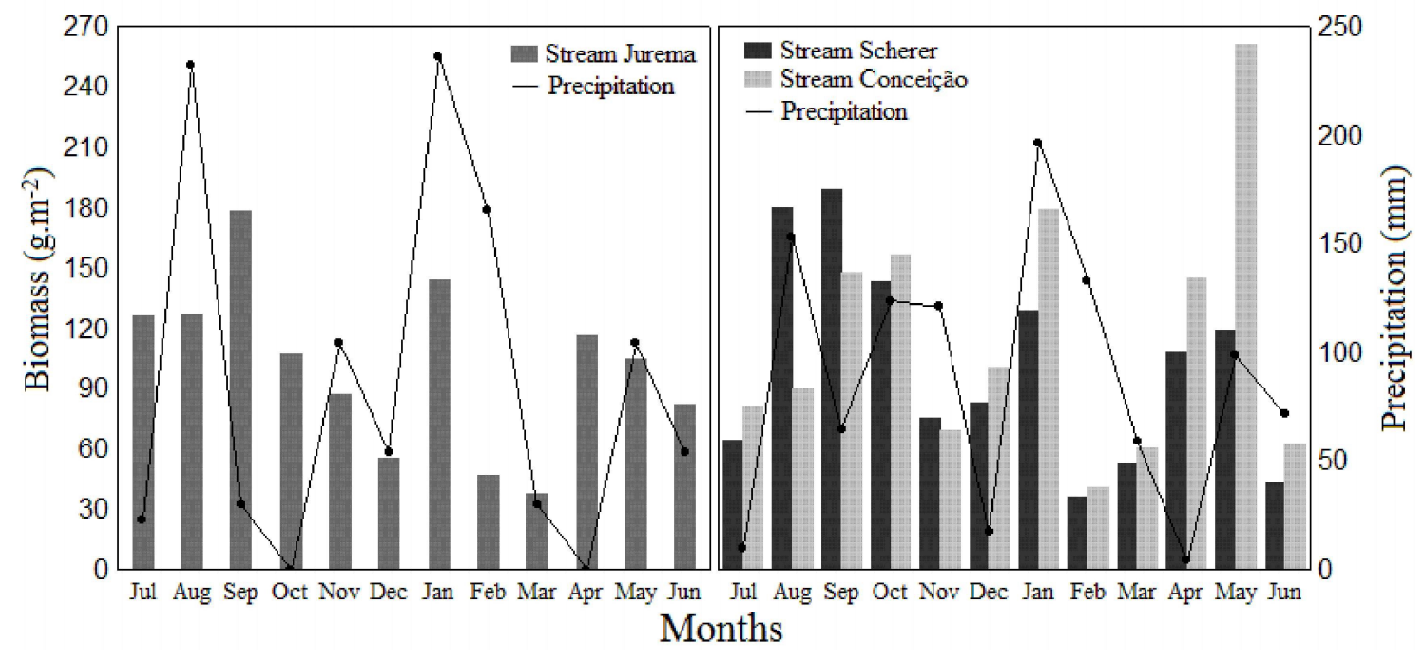

Figure 4 - Relations between monthly means of rainfall and leaf biomass (mean vertical load + mean terrestrial load) in Jurema Stream, Scherer Stream and Conceição Stream, between July 2008 and June 2009.

Figura 4 - Relação entre as médias mensais de chuvas e biomassa foliar (média da entrada vertical + entrada terrestre) no riacho Jurema, riacho Scherer e riacho Conceição, entre julho de 2008 e junho de 2009.

registered peaks of organic matter input during spring, in September and October/November, respectively, at the end of the dry period. For Jurema Stream, the peaks of leaf input and stock occurred in September, after increased rainfall in the previous month, and January, after a decrease rainfall register in the previous month. For Scherer and Conceição, the peaks were registered in October and January, both after a decrease in rainfall in the previous months. The first hypothesis was rejected, since peaks were also observed after rainy periods. There are different factors acting over leaf litter deposition in the studied region, since rainfall or physiological drought can contribute together or separately to input and standing stock in different periods. Leaf litter deposition in Semi-deciduous Forests can be strongly influenced by a decrease in the rain, due to hydric stress, and it may be more important than decrease in temperature and photoperiod (PEDRONI, 2002). In other studies, the end of the dry season has been related as a possible trigger to leaf litter input (JUSTINIANO; FREDERICKSEN, 2000; MORELLATO, 2000; GONÇALVES; CALLISTO, 2013).

The highest biomass input of leaves was registered in the lateral load, possibly influenced by the action of wind and, especially, runoff, associated with steepness of the stream banks. Carvalho and Uieda (2010) using a similar methodology reported that lateral load contributed significantly to leaf entrance to the streams and related to the influence of wind and rain. Even though lateral load was the most important leaf entrance to the streams, it was not correlated to the benthic stock biomass. The entrance of all inputs together and high retention should directly influence benthic stock biomass, but we did not observed positive correlation of all inputs biomass to benthic stock, leading to the rejection of the second hypothesis. It is possible that channel morphology and water velocity favored litter transport from benthic stock, decreasing retention inside the stream channel. On the other hand, there was a great amount of litter retention on the margins, which accumulate around trees and fallen branches, covering the forest floor, influencing the representativeness of lateral load.

\section{CONCLUSION}

Riparian forests are intimately linked to aquatic food webs, and the particulate organic matter provided by the trees are of special importance to the functioning of these systems (KIFFNET; RICHARDSON, 2010). The studied streams flow through preserved forested areas it is evident that the leaf biomass input from riparian vegetation is highly representative $(71.9 \%$ of all sampled material), accumulating in the stream banks and entering the streams in defined peaks, both after decreased or increased rainfall intensity. 


\section{ACKNOWLEGMENTS}

The authors would like to thank all those who helped in the field/lab work: José Nelson Campanha and Doraci de Oliveira in behalf of Instituto Ambiental do Paraná (IAP) for providing accommodation and support for all the field work; CNPq and CAPES, for financial support; Nupelia/UEM for logistic support; and Jaime Luiz Lopes Pereira and Celso Pereira dos Santos, for technician support to this work.

\section{REFERENCES}

ABELHO, M. From litterfall to breakdown in streams: a review. The Scientific World, v.1, p.656-680, 2001.

CARVALHO, E.M.; UIEDA, V.S. Input of litter in deforested and forested areas of a tropical headstream. Brazilian Journal of Biology, v.70, p.283-288, 2010.

FRANÇA, J.S.; GREGÓRIO, R.S.; PAULA J.D.; GONÇALVES JÚNIOR, J.F.; FERREIRA, A.F.; CALLISTO, M. Composition and dynamics of allochthonous organic matter inputs and benthic stock in a Brazilian stream. Marine and Freshwater Research, v.60, p.990-998, 2009.

GREGÓRIO, R.S.; VALENTIN, G.; FERREIRA, F.A.; Aleixo, L.A.; FRANÇA, J.S.; GONÇALVES JUNIOR, J.F.; CALLISTO, M.; BATISTA, M.L.; GASPAR R.O.; RODELLO, C.M.R. Contribuição foliar alóctone de espécies vegetais num córrego de $2^{a}$ ordem na Estação Ambiental de Peti (CEMIG) - MG. Revista Brasileira de Biociências v.5, n.1, p.33-35, 2007.

GONÇALVES, J.J.F.; CALLISTO, M. Organicmatter dynamics in the riparian zone of a tropical headwater stream in Southern Brasil. Aquatic Botany, v. 109, n.1, p.8-13, 2013.

GONÇALVES JUNIOR, J.F.; FRANÇA, S.J.; CALLISTO, M. Dynamics of Allochthonous organic matter. Brazilian Archives of Biology and Technology, v.49, p.967-973, 2006.

GONÇALVES JUNIOR, J.F.; REZENDE, R.S.; GREGÓRIO, R.S.; VALENTIN, G.C. Relationship between dynamics of litterfall and riparian plant species in a tropical stream. Limnologica, v.44, n.1,p.40-48, 2014.

HAUER, F.R.; HILL, W.R. Temperature, light, and oxygen. Methods in stream ecology. New York: Academic Press/Elsevier, 2006.

INSTITUTO AMBIENTAL DO PARANÁ - IAP. Plano de manejo da Reserva Florestal de Jurema. Paranavaí: 1996. p. 10.

JUSTINIANO, M.J.; FREDERICKSEN, T.S. Phenology of tree species in Bolivian dry forests. Biotropica, v.32, p.276-281, 2000.

KIFFNEY, P.M.; RICHARDSON, J.S. Organic matter inputs into headwater streams of southwestern British Columbia as a function of riparian reserves and time since harvesting. Aquatic Botany, v. 109, n.1, p.8-13, 2010.

MAGANA, A.E.M. Litter input from riparian vegetation to streams: a case study of the Njoro River, Kenya. Hydrobiologia, v.458, n.1, p.141-149, 2001.

MINSHALL, G.W. Role of allochthonous detritus in the trophic structure of a woodland sprinbrook community. Ecology, v.46, n.1, p.139-149, 1967.

MORELLATO, L.P.C. et al. Phenology of Atlantic rain forest trees: a comparative study.

Biotropica, v.32, p.811-823, 2000.

NIN, C.S.; RUPPENTHAL, E.L.; RODRIGUES, G.G. Produção de folhiço e fauna associada de macroinvertebrados aquáticos em curso d'água de cabeceira em Floresta Ombrófila Estado do Rio Grande do Sul, Brasil. Acta

Scientiarum. Biological Sciences, v.31, n.3, p.263-271, 2009.

PAGANO, S.N.; DURIGAN, G. Aspectos da Ciclagem dos Nutrientes em Matas Ciliares do Oeste do estado de São Paulo, Brasil. In: Matas ciliares: conservação e recuperação, LEITÃO FILHO, H.F.; RODRIGUES, R.R. (Ed.). São Paulo: FAPESP; 2000. p.109-121.

PEDRONI, F.;SANCHEZ, M.; SANTOS, F.A.M. Fenologia da copaíba (Copaifera langsdorffii

Revista Árvore, Viçosa-MG, v.40, n.1, p.89-96, 2016

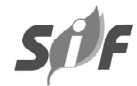


Desf. - Leguminosae, Caesalpinioideea) em uma floresta semidecídua no sudeste do Brasil.

Revista Brasileira de Botânica, v.25, n.1, p.183-194, 2002.

PEREIRA G.F. Estrutura de uma floresta ripária na Estação Ecológica do Caiuá, Diamante do Norte, PR, Brasil: Ribeirão Scherer. 2012. $55 \mathrm{f}$. Tese (Programa de Pós-Graduação em Ecologia de Ambientes Aquáticos Continentais) -

Universidade Estadual de Maringá, Maringá, 2012.

RICKLEFS, R.E.A. Economia da natureza. Rio de Janeiro: Guanabara Koogan, 2010.

SANPERA-CALBET, I.; LECERF, A.; CHAUVET, E. Leaf diversity influences in-stream litter decomposition through effects on shredders.
Freshwater Biology, v.54, p.1671-1682, 2009.

TREVISAN, A.; HEPP, L.U. Dinâmica de componentes químicos vegetais e fauna associada ao processo de decomposição de espécies arbóreas em um riacho do norte do Rio Grande do Sul, Brasil. Neotropical Biology and Conservation, v.2, n.1, p.55-60, 2007.

VANNOTE, R.L.; MINSHALL, G.W.; SEDELL, J.R.; CUSHING, C.E. The river continuun concept.

Canadian Journal of Fisheries and Aquatic Sciences, v.37, n.1, p.130-137, 1980.

VITAL, A.R.T.; GUERRINI, I.A.; FRANKEN, W.K.; FONSECA, R.C.B. Produção de serrapilheira e ciclagem de nutrientes de uma floresta estacional semidecidual em zona ripária. Revista Árvore, v.28, n.6, p.793-800, 2004. 